Western University Scholarship@Western

2-21-2014

\title{
Averting Lemur Extinctions amid Madagascar's Political Crisis
}

Christoph Schwitzer

Bristol Zoological Society, Bristol, UK

Russell Mittermeier

Conservation International, Washington, D.C.

Steig Johnson

University of Calgary

Giuseppe Donati

Oxford Brookes University

Mitchell Irwin

Northern Illinois University

See next page for additional authors

Follow this and additional works at: https://ir.lib.uwo.ca/anthropub

Part of the Biodiversity Commons, Biological and Physical Anthropology Commons, Environmental Policy Commons, Forest Management Commons, Population Biology Commons, and the Zoology Commons

Citation of this paper:

Schwitzer et al. (2014). "Averting Lemur Extinctions amid Madagascar's Political Crisis". Science 343 (6173): 842-843. 


\section{Authors}

Christoph Schwitzer, Russell Mittermeier, Steig Johnson, Giuseppe Donati, Mitchell Irwin, Heather Peacock, Jonah Ratsimbazafy, Josia Razafindramanana, Edward E. Louis, Lounes Chikhi, Ian C. Colquhoun, Jennifer Tinsman, Ranier Dolch, Marni LaFleur, Stephen Nash, Erik Patel, Blanchard Randrianambinina, Tove Rasolofoharivelo, and Patricia C. Wright 


\section{Averting Lemur Extinctions amid Madagascar's Political Crisis}

\author{
C. Schwitzer, ${ }^{1 *}$ R. A. Mittermeier, ${ }^{2}$ S. E. Johnson, ${ }^{3}$ G. Donati, ${ }^{4}$ M. Irwin, ${ }^{5}$ H. Peacock, ${ }^{6}$ \\ J. Ratsimbazafy, ${ }^{7,8}$ J. Razafindramanana, ${ }^{8}$ E. E. Louis Jr., ${ }^{9}$ L. Chikhi, ${ }^{10,11}$ I. C. Colquhoun, ${ }^{12}$ \\ J. Tinsman, ${ }^{13}$ R. Dolch, ${ }^{14}$ M. LaFleur, ${ }^{15}$ S. Nash, ${ }^{2,16}$ E. Patel, ${ }^{17}$ B. Randrianambinina, ${ }^{18}$ \\ T. Rasolofoharivelo, ${ }^{8}$ P. C. Wright ${ }^{16}$
}

$\mathrm{T}$ he most threatened mammal group on Earth, Madagascar's five endemic lemur families (lemurs are found nowhere else) (1), represent more than $20 \%$ of the world's primate species and $30 \%$ of family-level diversity. This combination of diversity and uniqueness is unmatched by any other country-remarkable considering that Madagascar is only 1.3 to $2.9 \%$ the size of the Neotropics, Africa, or Asia, the other three landmasses where nonhuman primates occur. But lemurs face extinction risks driven by human disturbance of forest habitats. We discuss these challenges and reasons for hope in light of site-specific, local actions proposed in an emergency conservation action plan (2).

\section{Political Crisis, Remarkable Threat}

An International Union for Conservation of Nature (IUCN) Species Survival Commission (SSC) Red List reassessment found that $94 \%$ of lemur species are threatened (2) (fig. S1 and table S1), up from $74 \%$ in 2008, which makes lemurs the most imperiled group of large vertebrates. Although other large mammals are also under pressure, for the vast majority of taxa in an entire infraorder (Lemuriformes) to be threatened is new, notable, and disturbing. This reevaluation has resulted from both the deterioration of habitat and the recent application of genetic data to phylogenetic analyses

${ }^{1}$ Bristol Zoological Society, Bristol BS8 3HA, UK. ${ }^{2}$ Conservation International, Arlington, VA 22202, USA. ${ }^{3}$ University of Calgary, Calgary, Alberta T2N 1N4, Canada. ${ }^{4}$ Oxford Brookes University, Oxford OX3 OBP, UK. ${ }^{5}$ Northern Illinois University, DeKalb, IL 60115, USA. ${ }^{6}$ Golder Associates, Calgary, Alberta T2A 7W5, Canada. ${ }^{7}$ Durrell Wild life Conservation Trust, Antananarivo 101, Madagascar. ${ }^{8}$ Groupe d'Etude et de Recherche sur les Primates de Madagascar, Antananarivo 101, Madagascar. ${ }^{9}$ Omaha's Henry Doorly Zoo, Omaha, NE 68107, USA ${ }^{10}$ Instituto Gulbenkian de Ciência, 2781-901 Oeiras, Portugal. ${ }^{11}$ Laboratoire Evolution et Diversité Biologique, CNRS UMR 5174 Université Paul Sabatier, 31062 Toulouse cedex 9, France. ${ }^{12}$ Western University, London, Ontario N6A 5C2, Canada. ${ }^{13}$ American Museum of Natural History, New York NY 10024, USA. ${ }^{14}$ Association Mitsinjo, Andasibe 514, Madagascar. ${ }^{15}$ University of Veterinary Medicine Vienna, 1210 Vienna, Austria. ${ }^{16}$ Stony Brook University, Stony Brook, NY 11794, USA. ${ }^{17}$ Duke Lemur Center, Durham, NC 27705, USA. ${ }^{18}$ Université de Mahajanga, Mahajanga 401, Madagascar. *Corresponding author. cschwitzer@bcsf.org.uk

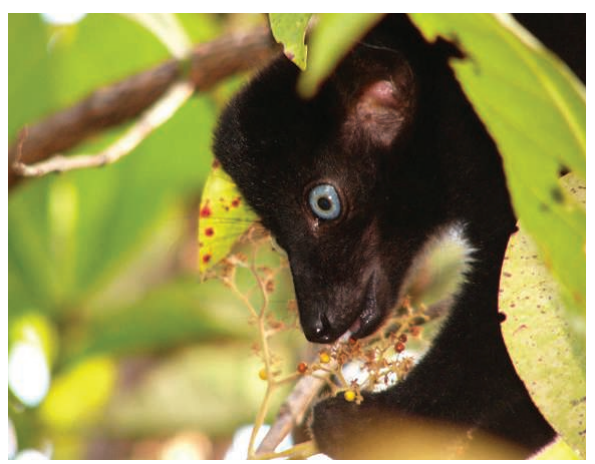

Male blue-eyed black lemur. Eulemur flavifrons in Sahamalaza-Iles Radama National Park.

(increasing the number of extant lemur species from 43 to 101) (3), revealing more species with smaller ranges.

This unique primate diversity relies on forest habitats that are shrinking under persistent anthropogenic destruction and disturbance. Remaining intact forest habitat was estimated to cover $92,200 \mathrm{~km}^{2}$ in 2010 , only 10 to $20 \%$ of Madagascar's original forest cover and down from 106,600 km² in 1990 (4); much of this habitat is inadequately or not at all protected. Habitat and lemur conservation are interdependent: Lemurs have important ecological roles and are essential to maintaining the island's unique forests. Their loss would likely trigger extinction cascades (5).

Challenges to in situ lemur conservation are immense. Madagascar is one of the poorest countries in the world; more than $92 \%$ of Malagasy live on less than U.S. \$2/day (6). Although there is a paucity of published data compared to other lemur-related subjects, lemur poaching for bushmeat has drastically increased since the onset of the political crisis in $2009(7,8)$. Illegal logging of rosewood and ebony, mining, and slash-andburn agriculture are all causing lemur population declines, by habitat loss, fragmentation, and alteration. Protected areas have not been spared; for example, armed timber poachers extracting valuable hardwoods targeted Masoala and Marojejy National Parks in the northeast once local law enforcement broke down (9). Foreign demand, as well as political turmoil and corruption, drive these
Community-based management, ecotourism, and researchers' presence are proposed to prevent lemur extinctions.

destructive, and often unlawful, activities (8).

Effective management of Madagascar's protected areas, as well as creation of more reserves, will be critical to future conservation of lemurs. In 2003, only $\sim 3 \%(\sim 17,000$ $\mathrm{km}^{2}$ ) of Madagascar's land area was designated as protected. During the administration of former President Ravalomanana, conservation became a national priority. In 2003, Ravalomanana announced that the government would triple its protected areas. Some $30,000 \mathrm{~km}^{2}$ of community-based reserves were gazetted. As of January 2010, 47,000 $\mathrm{km}^{2}$ are officially protected, $\sim 8 \%$ of Madagascar's land area.

The creation of new protected areas has continued despite political instability brought on by the unconstitutional change of government in early 2009 . However, this process has been slowed by a breakdown of government presence and control in many regions, exacerbated by suspension of funding for environmental programs by most international donors in the wake of the political crisis (10). The U.S. Agency for International Development shelved a comprehensive 25-year environmental program until the country returns to democratic government (although humanitarian assistance continues), and several European governments have responded similarly. Only the World Bank has maintained its commitment, but even its substantial support has not been utilized effectively by the transitional government for the management of protected areas (11). Presidential elections, held in two rounds on 25 October and 20 December 2013, resulted in a narrow victory for former Finance Minister Hery Rajaonarimampianina. There are encouraging signs that the new president will set the conditions for a return to effective governance and resumption of international aid.

Outside the official protected areas, the situation is worse, with illegal slash-and-burn agriculture, logging, mining, and bushmeat hunting on the rise. Commercial lemur hunting, a practice previously unreported from the country, has been noted in regions such as Foulpointe, Vatomandry, Daraina, and the forests south of Antsiranana (Diego Suarez). 


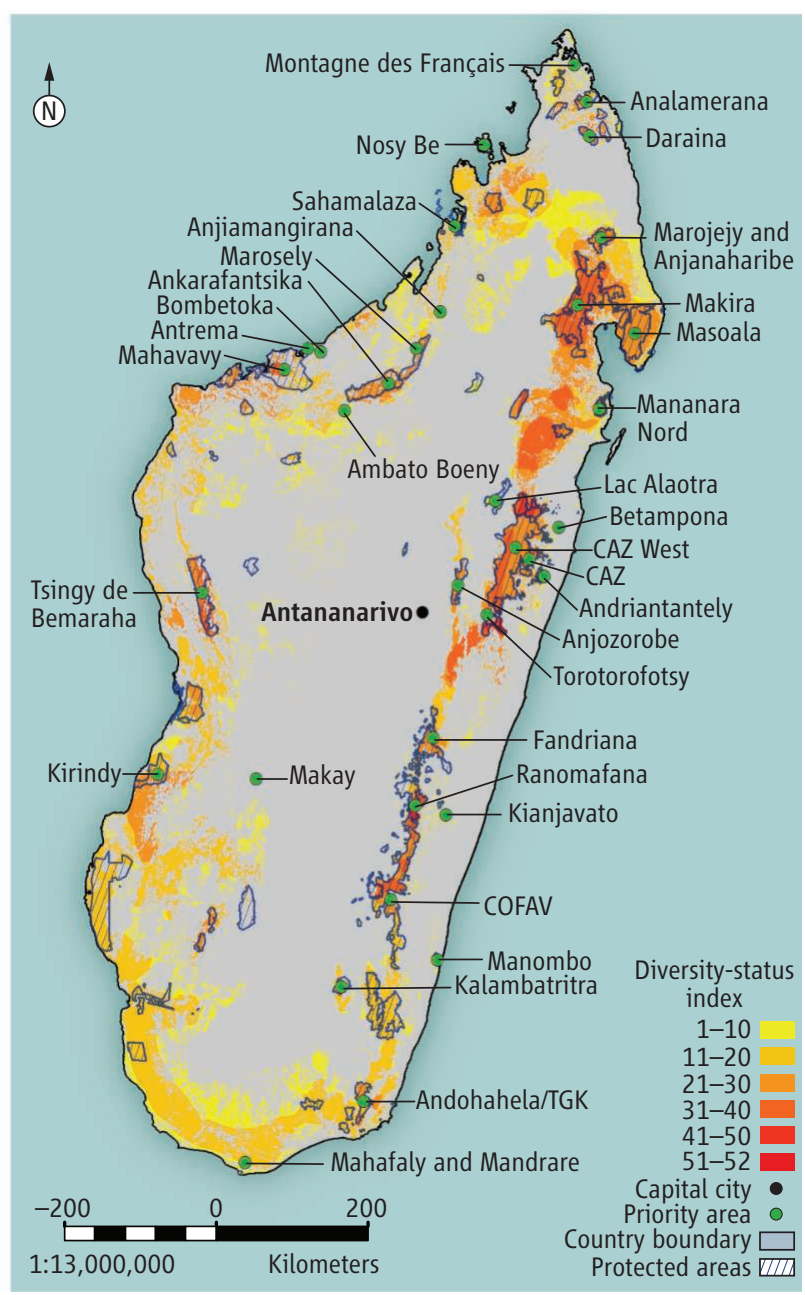

In several parts of the northeastern rain forests, large-bodied indris (Indri indri) and diademed sifakas (Propithecus diadema) are in danger of being extirpated (7).

\section{Tourism, Research, Local Management}

Despite these profound problems, we believe there is still hope. Overall, lemur conservation must tie in with national conservation efforts in Madagascar, such as expanding the protected area network and enforcing environmental laws. However, there are specific site-based actions that can be carried out by conservationists, researchers, and local communities, which are less expensive than national initiatives (2). The emergency 3-year action plan takes such an approach, combining a broad framework with concrete steps modeled on past successes. It proposes conservation actions for 30 priority sites harboring endangered lemurs (see the chart), for a total budget of U.S. \$7.6 million. This is a reasonable amount in terms of international aid, for an incalculable return. Major goals include stabilizing the immediate crisis in priority areas and laying the groundwork

Lemur species richness-extinction risk index and priority conservation areas. Each species range was given a weighting according to its estimated extinction risk (the likelihood of a species becoming extinct in the near future, given current knowledge about population trends, range, and recent, current or projected threats, expressed by its 2012 IUCN Red List status (1, Least Concern; 2, Near Threatened; 3, Vulnerable or Data Deficient; 4, Endangered; 5, Critically Endangered). All lemur species' range weightings were summed to provide the richness-risk index, a composite measure of richness and estimated extinction risk. For example, where two Near Threatened species co-occur, there is a value of 4, and where two Critically Endangered species co-occur, the value is 10. The color spectrum represents the continuum from areas with low species richness and lower extinction risk to areas with high species richness and high extinction risk. Hatched areas indicate terrestrial protected areas. Green dots show locations of priority areas for lemur conservation digitized from the 2013 to 2016 conservation action plan (2).CAZ, Corridor Ankeniheny-Zahamena; COFAV, Corridor Fandriana-Vondrozo; TGK, Tsitongambarika. See supplementary materials for details.

for longer-term actions in all habitats crucial for preventing lemur extinctions.

Promoting and expanding ecotourism is one important component of the action plan. Lemurs represent Madagascar's most distinctive "brand" for tourism. Ecotourism continues in spite of political problems and remains one of the country's most important foreignexchange earners, providing livelihoods for the rural poor in environmentally sensitive regions and often fostering local valuation of primates and ecosystems. Examples of implementation already exist and could be replicated, provided resources are available and there is sufficient community engagement to ensure appropriate investment. An important element of this is the development of local tourist guide associations.

Another key mechanism is the creation of protected areas managed at the community level. Despite the fact that such reserves may take a long time to establish, empowering local communities to create reserves and training them in management through small grants is where we are likely to see the greatest growth in habitat protection over the next decade.

Another goal is to sustain and expand long-term research presence in critical lemur sites. Field stations that support a permanent presence of local and international field workers - such as those at Ranomafana, Marojejy, Kirindy, Tsinjoarivo and Sahamalaza — can serve as training grounds for Malagasy scientists while deterring illegal hunting and logging (12). Scientists are working with local communities, providing economic benefits and knowledge exchange for conservation at local levels.
Past successes highlighted in the plan, such as Anja Community Reserve and Kianjavato Classified Forest, demonstrate that collaboration between local communities, nongovernmental organizations and researchers can protect imperiled species. We urgently invite all stakeholders to join our efforts to meet the action plan's goals and to ensure the continued existence of lemurs and the considerable biological, cultural and economic richness they represent. Madagascar - and the world - will undoubtedly be much poorer without them.

\section{References and Notes}

1. Two species have been introduced to the neighboring Comoro Islands in the past few hundred years.

2. C. Schwitzer et al., Lemurs of Madagascar: A Strategy for Their Conservation 2013-2016 (IUCN SSC Primate Specialist Group, Bristol Conservation and Science Foundation, and Conservation International, Bristol, 2013); https://portals.iucn.org/library/node/10414.

3. R. A. Mittermeier et al., Lemurs of Madagascar (Conservation International, Arlington, VA, ed. 3, 2010).

4. Office National pour l'Environnement (ONE) et al., Evolution de la Couverture de forêts naturelles à Madagascar 2005-2010 (ONE, Antananarivo, 2013); www.pnae.mg/ index.php/Autres/evolution-de-la-couverture-de-foretsnaturelles-a-madagascar-2005-2010.html.

5. J. U. Ganzhorn et al., Conserv. Biol. 13, 794 (1999).

6. World Bank, "Madagascar: Measuring the impact of the political crisis" (World Bank, Washington, DC, 2013); www.worldbank.org/en/news/feature/2013/06/05/madagascar-measuring-the-impact-of-the-political-crisis.

7. R. K. B. Jenkins et al., PLOS ONE 6, e27570 (2011).

8. M. A. Barrett et al., Science 328, 1109 (2010).

9. Global Witness, Environmental Investigation Agency, Investigation into the Illegal Felling, Transport and Export of Precious Wood in SAVA Region, Madagascar (Global Witness, London, 2009); www.parcs-madagascar. com/doc/report_vsfinal.pdf.

10. World Bank, The World Bank Adopts an Interim Strategy for Madagascar [press release] (World Bank, Washington, DC, 2012); http://go.worldbank.org/5XTWG1TGG0.

11. 1.-C. Carret, Madagascar Country Environmental Analysis (CEA): Taking Stock and Moving Forward (World Bank, Washington, DC, 2013).

12. W. F. Laurance, Trends Ecol. Evol. 28, 261 (2013).

Acknowledgments: We thank organizers and participants of the International Prosimian Congress, held in Ranomafana, Madagascar, 5 to 9 August, 2013, as well as the three anonymous reviewers of this manuscript. This paper is dedicated to Alison Jolly (1937-2014) in recognition of her dedication to the conservation of Madagascar's lemurs.

\section{Supplementary Material}

www.sciencemag.org/content/343/6173/842/suppl/DC1 